\title{
Nutritional Quality of Opuntia ssp. at Different Phenological Stages: Implications for Forage Purposes
}

\author{
Danilo Dantas da Silva (corresponding author) \\ Federal University of Paraíba, Areia, 58397-000, Paraíba, Brazil. \\ E-mail: danilo20silva@hotmail.com
}

\begin{abstract}
Alberício Pereira de Andrade
Federal University of Agreste of Pernambuco, Garanhuns, 55292-270, Pernambuco, Brazil.

E-mail: albericio3@gmail.com
\end{abstract}

Divan Soares da Silva

Federal University of Paraíba, Areia, 58397-000, Paraíba, Brazil.

E-mail: divan13silva@gmail.com

\begin{abstract}
Francisco Abel Lemos Alves
Agronomic Institute of Pernambuco, Caruaru, 55100-000, Pernambuco, Brazil.

E-mail: abel_agro@yahoo.com.br
\end{abstract}

\begin{abstract}
Roberta de Lima Valença
Federal University of Agreste of Pernambuco, Garanhuns, 55292-270, Pernambuco, Brazil.

E-mail: robertalimav@ hotmail.com
\end{abstract}

\begin{abstract}
Djalma Cordeiro dos Santos
Agronomic Institute of Pernambuco, Arcoverde, 56500-000, Pernambuco, Brazil.

E-mail: djalma.cordeiro@ipa.br
\end{abstract}

Ariosvaldo Nunes de Medeiros

Federal University of Paraíba, Areia, 58397-000, Paraíba, Brazil.

E-mail: ariosvaldo.medeiros@gmail.com 
Fernando dos Santos Araújo

Federal University of Agreste of Pernambuco, Garanhuns, 55292-270, Pernambuco, Brazil. E-mail: fernandoaraujoagro177@gmail.com

\author{
Lucas Kennedy Silva Lima \\ Embrapa Mandioca e Fruticultura, Cruz das Almas, 44380-000, Bahia, Brazil. \\ E-mail: lucas18kennedy@gmail.com
}

Riselane de Lucena Alcantara Bruno

Federal University of Paraíba, Areia, 58397-000, Paraíba, Brazil.

E-mail: lanebruno.bruno@gmail.com

Received: November 16, 2021 Accepted: December 23, 2021 Published: Decembeer 28, 2021

doi:10.5296/jas.v10i1.19199

URL: https://doi.org/10.5296/jas.v10i1.19199

\begin{abstract}
The study aimed to evaluat the chemical composition of forage cactus cladodes of the genus Opuntia spp. at different stages of phenological development. The experiment was conducted in a completely randomized design, with a $4 \times 3$ factorial scheme, with four species of cactus (Opuntia stricta Haw, Opuntia undulata Griffiths, Opuntia atropes Rose and Opuntia larreri FAC Weber) and three stages of cladode development (young, intermediate, and mature). The chemical composition of Opuntia cladodes varied according to species and phenological stage. Dry matter (DM), neutral detergent fiber (NDF) and acid detergent fiber (ADF) concentrations increased, and crude protein $(\mathrm{CP})$ decreased with cladode maturation. The species $O$. atropes had the lowest levels of organic matter (OM), CP, total carbohydrates, and non-fibrous carbohydrates, as well as the highest values of mineral matter, NDF and ADF. Calcium and phosphorus contents increased with cladodium maturation. The concentrations of boron, copper and manganese were higher in the young and intermediate stages. The cladodes of $O$. stricta, $O$. undulata and $O$. larreri showed better nutritional quality for feeding domestic ruminants. Young and intermediate cladodes are more proteinaceous and less fibrous. These results can be useful in selecting the forage cactus species and in optimizing the use of cladodes for feeding different categories of ruminants in semiarid regions.
\end{abstract}

Keywords: animal feed, chemical composition, Erect Prickly Pear, mineral composition, V-19 


\section{Introduction}

The lack of forage for animal feeding during the dry season is one of the main difficulties faced by domestic ruminant breeders in the Brazilian semiarid region. However, this barrier has been circumvented by the use of succulent stems (cladodes) of Cactaceae of the genera Opuntia and Nopalea, commonly called "forage cactus", as a source of water and energy to supplement herds in the dry season (Oliveira et al., 2021).

The genus Opuntia has about 300 species, being one of the most used in Northeast Brazil for foraging purposes (Lucena et al., 2013). Its CAM photosynthetic metabolism (Crassulaceous Acid Metabolism) favors the efficient use of water (Ferraz et al., 2017), enabling cultivation in arid and semi-arid regions (Edvan et al., 2020).

Cladodes have a high concentration of non-fibrous carbohydrates (585.5 g.kg-1 of DM) and total digestible nutrients (800.0 g.kg $\left.{ }^{-1} \mathrm{DM}\right)$ (Silva \& Sampaio, 2015). Although the contents of CP (41.0 - 63.0 g.kg ${ }^{-1}$ DM), NDF (243.0 - 302.0 g.kg-1 DM) and ADF (105.0 - 178.0 g.kg ${ }^{-1}$ DM) show some limitations to ruminants feeding, an adequate balance of the diet with the addition of fiber and protein can overcome this disadvantage (Moraes et al., 2019; Silva et al., 2019; Siqueira et al., 2018).

Cladodes are also rich in minerals, mostly calcium (21.4 - $\left.62.7 \mathrm{~g} . \mathrm{kg}^{-1} \mathrm{DM}\right)$, potassium (4.6 42.0 g.kg $\left.{ }^{-1} \mathrm{DM}\right)$, manganese (102.5 - $\left.704.5 \mathrm{mg} . \mathrm{kg}^{-1} \mathrm{DM}\right)$, iron $\left(59.3\right.$ to $\left.208.2 \mathrm{mg} . \mathrm{kg}^{-1} \mathrm{DM}\right)$ and zinc (19.1 - $81.1 \mathrm{mg} \cdot \mathrm{kg}^{-1} \mathrm{DM}$ ) (Alves et al., 2017). However, mineral composition can be varied due to edaphoclimatic conditions, plant age, time of year, management practices, species, and genotypes (Dubeux Jr et al., 2021).

Forage cactus are an important resource for semiarid regions and has been widely studied from a nutritional point of view (Cordova-Torres et al., 2015; Vazquez-Mendoza et al., 2017; Pessoa et al., 2020). However, some aspects need a better understanding, such as nutritional quality, especially mineral composition of cladodes as a function of species/genotype and plant development stage. Thus, this study aimed to evaluate the chemical-bromatological and mineral composition of Opuntia species at different stages of phenological development, analyzing its implications for forage purposes.

\section{Method}

\subsection{Obtaining Samples}

Cladode samples of four species of Opuntia (Table 1) were collected in May 2018 at the experimental station of the Instituto Agronômico de Pernambuco (IPA) in Arcoverde (-8.43 ${ }^{\circ}$ S, $-37.06^{\circ} \mathrm{W}$; altitude $683.9 \mathrm{~m}$ ), state of Pernambuco, Brazil. Planting was established in December 2014 (spacing $1.0 \times 0.5 \mathrm{~m}$ ) and handled in an upland system with classic cultural treatments, including periodic weeding and organic fertilization $\left(20 \mathrm{t}^{-\mathrm{ha}^{-1}}\right.$ of cattle manure each two years). The local climate based on the Köppen-Geiger classification is BSh (hot and dry) with averages of annual temperature of $24.9 \pm 1.97{ }^{\circ} \mathrm{C}$, reactive humidity of $78.19 \pm$ $8.24 \%$ and accumulated precipitation of $798.1 \mathrm{~mm}$ per year (INMET, 2019). 
Table 1. Genotypes of species of the genus Opuntia spp. used in the study

\begin{tabular}{lll}
\hline Species & Access & Genotype \\
\hline Opuntia stricta Haw & IPA-200016 & Erect Prickly Pear (EPP) \\
Opuntia undulata Griffiths & IPA-200174 & African Prickly Pear (APP) \\
Opuntia atropes Rose & IPA-200008 & F-08 \\
Opuntia larreri F.A.C. Weber & IPA-200149 & V-19 \\
\hline
\end{tabular}

The soil physicochemical characteristics in the cultivation area ( 0 to $20 \mathrm{~cm}$ deep) were analyzed according to the methodology proposed by Teixeira et al. (2017) (Table 2). The local climate data during the trial (2014 to 2018) were provided by the automatic meteorological station of the National Institute of Meteorology (INMET) (Figure 1).

Table 2. Physical-chemical attributes of the soil of the cultivated area with species genotypes of the genus Opuntia spp.

\begin{tabular}{|c|c|c|c|c|c|c|c|c|c|c|}
\hline \multirow{2}{*}{$\begin{array}{c}\mathrm{pH} \\
(1: 2.5)\end{array}$} & $\mathrm{P}$ & $\mathrm{K}^{+}$ & $\mathrm{Na}^{+}$ & $\mathrm{H}^{+}+\mathrm{Al}^{3+}$ & $\mathrm{Al}^{3+}$ & $\mathrm{Ca}^{2+}$ & $\mathrm{Mg}^{2+}$ & SB & $\mathrm{CEC}$ & \multirow{2}{*}{$\begin{array}{l}\mathrm{OM} \\
\mathrm{g} / \mathrm{kg}\end{array}$} \\
\hline & \multicolumn{2}{|c|}{$---\mathrm{mg} / \mathrm{dm}^{3}---$} & \multicolumn{7}{|c|}{ 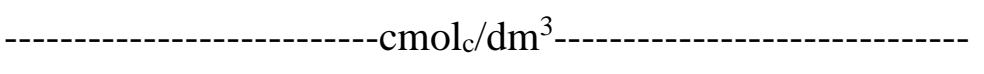 } & \\
\hline 6.42 & 24.37 & 119.96 & 0.15 & 4.07 & 0.00 & 6.38 & 0.86 & 7.70 & 11.77 & 20.48 \\
\hline \multicolumn{3}{|c|}{ Sand } & \multicolumn{2}{|l|}{ Silt } & \multicolumn{2}{|c|}{ Clay } & \multicolumn{4}{|c|}{ Textural classification } \\
\hline \multicolumn{3}{|c|}{717} & \multicolumn{2}{|l|}{180} & \multicolumn{2}{|c|}{103} & \multicolumn{4}{|c|}{ Sandy-loam } \\
\hline
\end{tabular}

$S B$, sum of bases; $C E C$, cation exchange capacity; $O M$, organic matter. 


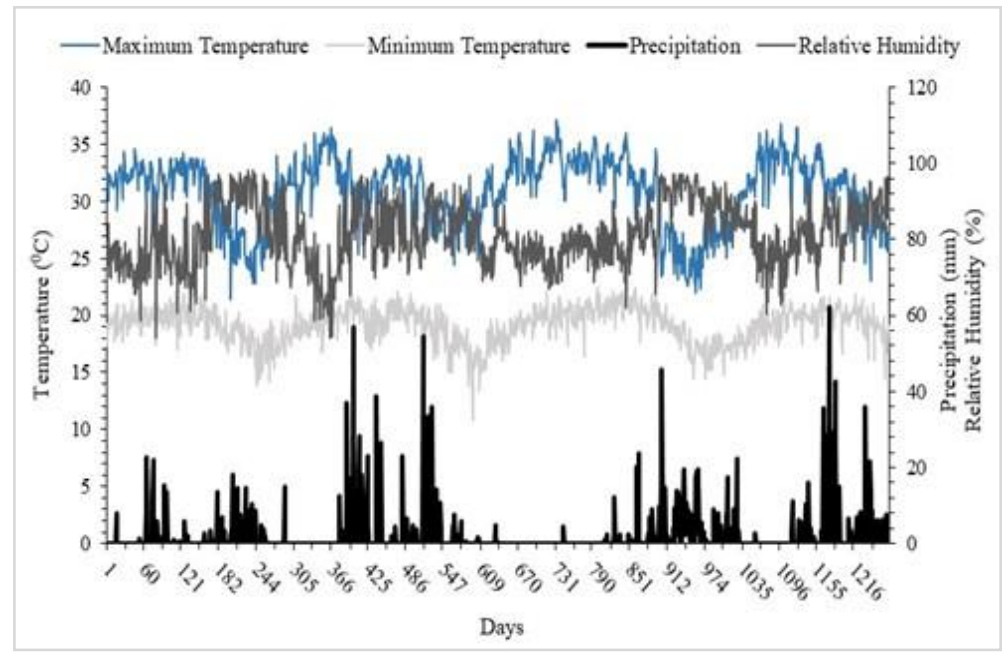

Figure 1. Precipitation $(\mathrm{mm})$, temperature $\left({ }^{\circ} \mathrm{C}\right)$ and relative humidity $(\%)$ in the cultivated area with species genotypes of the genus Opuntia spp.

Cladodes were collected from five plants of each genotype $(n=5)$ at three phenological stages: young (expanding cladodes, with fragile structure and light green color, located at the distal or lateral ends of the plant), intermediate (cladodes with rigid structure and dark green color, located in the middle part of the plant) and mature (fully expanded cladodes, with rigid structure and whitish-green color, located in primary order, just above the base). After collection, the samples were cleaned, chopped, and dehydrated in a forced air oven at a temperature of $55^{\circ} \mathrm{C}$ for 72 hours. Then, crushed in a knife mill with a $1 \mathrm{~mm}$ sieve, identified, packed in plastic containers with airtight closure and stored at $25^{\circ} \mathrm{C}$.

\subsection{Chemical Analysis and Nutritional}

Dry matter (934.01), organic matter (942.05), crude protein (954.01), ether extract (EE) (920.39) and mineral matter (MM) (942.05) were performed according to the Association of Official Analytical Chemists (AOAC, 1990). Neutral and acid were determined using the methodology of Van Soest et al. (1991), adapted by Senger et al. (2008). Total carbohydrates (TC) were estimated using the equation described by Sniffen et al. (1992): TC = $1000-(\mathrm{CP}+$ $\mathrm{EE}+\mathrm{MM}$ ), and non-fibrous carbohydrates (NFC) according to Van Soest et al. (1991): NFC $=1000-(\mathrm{CP}+\mathrm{EE}+\mathrm{MM}+\mathrm{NDF})$.

Samples were mineralized in sulfuric acid in order to evaluate nitrogen $(\mathrm{N})$; in a mixture of nitric-perchloric acid, in order to determine phosphorus $(\mathrm{P})$, potassium $(\mathrm{K})$, calcium $(\mathrm{Ca})$, magnesium $(\mathrm{Mg})$, sulfur $(\mathrm{S})$, copper $(\mathrm{Cu})$, manganese $(\mathrm{Mn})$, iron $(\mathrm{Fe})$ and zinc $(\mathrm{Zn})$; and incinerated to determine boron (B). N concentration was determined by the Kjeldahl method; $\mathrm{P}$ by molybdenum blue colorimetry; $\mathrm{K}$ by emission flame photometry; $\mathrm{Ca}, \mathrm{Mg}, \mathrm{Cu}, \mathrm{Mn}, \mathrm{Fe}$ and $\mathrm{Zn}$ through atomic absorption spectrophotometry; and $\mathrm{S}$ by barium sulfate turbidimetry, according to Malavolta et al. (1997). The concentration of B was determined by the azomethine-H colorimetry method (Silva, 2009).

\subsection{Statistical Analysis}

The experimental design used was completely randomized in a 4 x 3 factorial scheme 
(genotypes of four species and three phenological stages of the cladode) and five replications. The data met the assumptions for parametric analysis and were subjected to analysis of variance at the $5 \%$ probability level $(\mathrm{P}<0.05)$. Treatment means were compared by the Tukey test using the Statistical Analysis System $\left(\right.$ SAS $\left.^{\circledR}\right)$ software (Cody, 2015). The statistical model adopted was:

$\mathrm{Y}_{\mathrm{ijk}}=\mu+\mathrm{G}_{\mathrm{i}}+\mathrm{P}_{\mathrm{j}}+\mathrm{GP}_{\mathrm{ij}}+\mathrm{E}_{\mathrm{ijk}}$

Where: $Y_{i j k}$ is the observed value for the analyzed variable, $\mu$ overall mean, $G_{i}$ is the effect of the genotype of species $i, P_{j}$ is the effect of the phenological stage $j, G P_{i j}$ is the effect of the interaction between $G_{i} x P_{j}$, and $E_{i j k}$ the experimental error associated with $Y_{i j k}$.

Data were also submitted to multivariate analysis for exploratory purposes. In the cluster analysis, the Gower distance, and the hierarchical method UPGMA (Unweighted Peer Group with Arithmetic Mean) were used. In the Principal Component Analysis (PCA) treatments were plotted in relation to the first two components (PC1 and PC2). These evaluations were performed with the prcomp function in the statistical program R (R Core Team, 2018).

\section{Results}

\subsection{Chemical Composition of Cladodes}

There was interaction $(\mathrm{P}<0.05)$ between the genotypes and phenological stages of the cladode in EE concentration, but for DM, OM, CP, and MM isolated effects of the factors were verified $(\mathrm{P}<0.05)$ (Table 3). The EE content in EPP was higher in young cladodes and APP in the intermediate stage (22.68 g. kg $\left.{ }^{-1} \mathrm{DM}\right)$ compared to the young (19.56 g. kg-1 DM), but it presents similar content to that of mature cladodes (20.36 g). g. $\left.\mathrm{kg}^{-1} \mathrm{DM}\right)$. Concentrations in intermediate and mature cladodes were higher in APP and V-19 (Table 3).

The DM content differed between species ( $\mathrm{P}<0.05)$, being higher in EPP $\left(67.93 \mathrm{~g} . \mathrm{kg}^{-1}\right.$ of natural matter - NM) when compared to V-19 (61.43 g.kg-1 NM), and both similar to APP and F-08. Regarding the developmental stages, mature cladodes (68.39 g. $\left.\mathrm{kg}^{-1} \mathrm{MN}\right)$ had a higher concentration of DM than young cladodes $\left(62.46 \mathrm{~g} \cdot \mathrm{kg}^{-1} \mathrm{MN}\right)$.

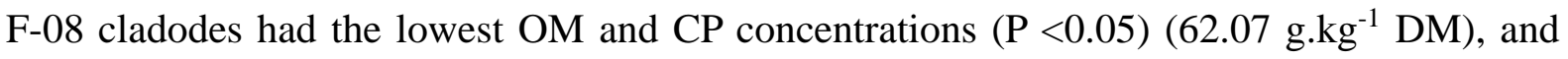
the highest MM concentration (181.83 g. $\left.\mathrm{kg}^{-1} \mathrm{DM}\right)$ (Table 3). The CP content was higher $(\mathrm{P}<$ $0.05)$ in young cladodes (71.72 g.kg-1 DM) compared to mature cladodes (64.88 g.kg-1 DM) and similar to intermediates (68.68 g.kg-1 DM). 
Table 3. Chemical composition of species genotypes of the genus Opuntia spp. in different phenological stages

\begin{tabular}{|c|c|c|c|c|c|c|c|c|c|}
\hline \multirow{2}{*}{$\begin{array}{l}\text { Phenological } \\
\text { stages }\end{array}$} & \multicolumn{5}{|c|}{ Genotypes } & \multirow{2}{*}{ SEM } & \multirow{2}{*}{\multicolumn{3}{|c|}{ P-value }} \\
\hline & EPP & APP & F-08 & V-19 & Average & & & & \\
\hline & \multicolumn{6}{|c|}{ Dry Matter (DM, g.kg ${ }^{-1}$ Natural Matter) } & G & $\mathrm{P}$ & $\mathrm{G} \times \mathrm{P}$ \\
\hline Young & 66.88 & 62.24 & 62.14 & 58.60 & $62.46 \mathrm{~B}$ & 1.26 & & & \\
\hline Intermediate & 66.04 & 65.32 & 67.15 & 60.43 & $64.74 \mathrm{AB}$ & 1.09 & 0.009 & 0.002 & $>0.050$ \\
\hline Mature & 70.86 & 68.16 & 69.30 & 65.25 & $68.39 \mathrm{~A}$ & 1.26 & & & \\
\hline \multirow[t]{2}{*}{ Average } & $67.93 a$ & $65.24 \mathrm{ab}$ & $66.20 \mathrm{ab}$ & $61.43 b$ & & & & & \\
\hline & \multicolumn{6}{|c|}{ Organic Matter (OM, g.kg ${ }^{-1}$ Dry Matter) } & & & \\
\hline Young & 858.53 & 855.15 & 807.25 & 857.09 & 844.50 & 6.28 & & & \\
\hline Intermediate & 856.54 & 843.15 & 810.42 & 840.64 & 837.69 & 5.83 & $<0.001$ & $>0.050$ & 0.140 \\
\hline Mature & 840.59 & 851.22 & 836.84 & 853.32 & 845.49 & 4.31 & & & \\
\hline \multirow[t]{2}{*}{ Average } & $851.89 \mathrm{a}$ & $849.84 a$ & $818.17 b$ & $850.35 \mathrm{a}$ & & & & & \\
\hline & \multicolumn{6}{|c|}{ Crude Protein (CP, g. $\mathrm{kg}^{-1}$ Dry Matter) } & & & \\
\hline Young & 73.92 & 73.42 & 67.28 & 72.26 & $71.72 \mathrm{~A}$ & 1.53 & & & \\
\hline Intermediate & 69.10 & 71.26 & 62.87 & 71.50 & $68.68 \mathrm{AB}$ & 1.56 & $<0.001$ & 0.004 & $>0.050$ \\
\hline Mature & 64.98 & 68.56 & 56.06 & 69.94 & $64.88 \mathrm{~B}$ & 1.59 & & & \\
\hline \multirow[t]{2}{*}{ Average } & $69.33 \mathrm{a}$ & $71.08 \mathrm{a}$ & $62.07 \mathrm{~b}$ & $71.24 \mathrm{a}$ & & & & & \\
\hline & \multicolumn{6}{|c|}{ Ether Extract (EE, g. $\mathrm{kg}^{-1}$ Dry Matter) } & & & \\
\hline Young & $20.13 \mathrm{aA}$ & $19.56 \mathrm{aB}$ & $18.04 \mathrm{aA}$ & $20.03 \mathrm{aA}$ & 19.44 & 0.48 & & & \\
\hline Intermediate & $15.59 \mathrm{bB}$ & $22.68 \mathrm{aA}$ & $16.14 \mathrm{bA}$ & $20.25 \mathrm{aA}$ & 18.66 & 0.73 & $<0.001$ & $>0.050$ & $<0.001$ \\
\hline Mature & $16.46 \mathrm{cB}$ & $20.36 \mathrm{aAB}$ & $17.43 \mathrm{bA}$ & $22.40 \mathrm{aA}$ & 19.16 & 0.64 & & & \\
\hline \multirow[t]{2}{*}{ Average } & 17.39 & 20.87 & 17.20 & 20.89 & & & & & \\
\hline & \multicolumn{6}{|c|}{ Mineral Matter (MM, g.kg ${ }^{-1}$ Dry Matter) } & & & \\
\hline Young & 141.47 & 144.85 & 192.75 & 142.91 & 155.50 & 6.28 & & & \\
\hline Intermediate & 143.46 & 156.85 & 189.58 & 159.36 & 162.31 & 5.83 & $<0.001$ & $>0.050$ & 0.140 \\
\hline Mature & 159.41 & 148.78 & 163.16 & 146.68 & 154.51 & 4.31 & & & \\
\hline Average & $148.11 b$ & $150.16 \mathrm{~b}$ & $181.83 \mathrm{a}$ & $149.65 b$ & & & & & \\
\hline
\end{tabular}

EPP (Opuntia stricta); APP (Opuntia undulata); F-08 (Opuntia atropes); V-19 (Opuntia larreri). SEM, standard error of mean; $G$, genotypes; $P$, phenological stages; $G \times P$, interaction of genotypes and phenological stages. Means followed by lowercase letters differ in the rows and capital letters in columns $(\mathrm{P}<0.05)$.

NDF and ADF contents differed $(\mathrm{P}<0.05)$ between cladode species and developmental stages (Table 4). The F-08 presented lower NDF values in the intermediate (277.35 g. $\left.\mathrm{kg}^{-1} \mathrm{DM}\right)$ and young (282.36 g. kg-1 DM) cladodes, while in the mature stage it was higher $\left(357.63 \mathrm{~g} . \mathrm{kg}^{-1}\right.$ DM) than in the other species. ADF concentrations in APP (168.44 g.kg-1 DM) and F-08 (213.23 g. $\left.\mathrm{kg}^{-1} \mathrm{DM}\right)$ were higher in mature cladodes.

TC and NFC concentrations were not influenced $(\mathrm{P}>0.05)$ by the interaction between the factors and there was no effect $(\mathrm{P}>0.05)$ of developmental stages on these variables either (Table 4). Regarding the genotypes, it was found that the concentrations of TC (738.9

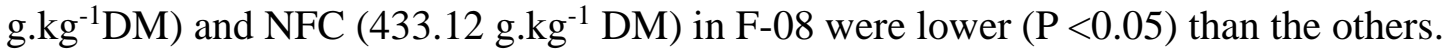


Table 4. Fiber compounds of species genotypes of the genus Opuntia spp. in different phenological stages

\begin{tabular}{|c|c|c|c|c|c|c|c|c|c|}
\hline \multirow{2}{*}{$\begin{array}{l}\text { Phenological } \\
\text { stages }\end{array}$} & \multicolumn{5}{|c|}{ Genotypes } & \multirow{2}{*}{\multicolumn{4}{|c|}{ P-value }} \\
\hline & EPP & APP & F-08 & $\mathrm{V}-19$ & Average & & & & \\
\hline & \multicolumn{6}{|c|}{ Neutral Detergent Fiber (NDF, g.kg ${ }^{-1}$ Dry Matter) } & $\mathrm{G}$ & $\mathrm{P}$ & $\mathrm{G} \times \mathrm{P}$ \\
\hline Young & $284.55 \mathrm{aA}$ & $267.87 \mathrm{aA}$ & $282.36 \mathrm{aB}$ & $254.85 \mathrm{aA}$ & 272.41 & 4.79 & & & \\
\hline Intermediate & $285.98 \mathrm{aA}$ & $264.81 \mathrm{aA}$ & $277.35 \mathrm{aB}$ & $255.86 \mathrm{aA}$ & 271.00 & 5.76 & $<0.001$ & 0.001 & 0.001 \\
\hline Mature & $269.89 \mathrm{bA}$ & $277.26 \mathrm{bA}$ & $357.63 \mathrm{aA}$ & $283.67 \mathrm{bA}$ & 297.11 & 9.14 & & & \\
\hline Average & 280.14 & 269.98 & 305.78 & 264.80 & & & & & \\
\hline \multicolumn{10}{|c|}{ Acid Detergent Fiber (ADF, g.kg-1 Dry Matter) } \\
\hline Young & $148.83 a A$ & $147.79 \mathrm{aB}$ & $162.59 \mathrm{aB}$ & $150.72 \mathrm{aA}$ & 152.48 & 3.38 & & & \\
\hline Intermediate & $153.40 \mathrm{aA}$ & $148.58 \mathrm{aB}$ & $159.57 \mathrm{aB}$ & $144.51 \mathrm{aA}$ & 151.51 & 2.75 & $<0.001$ & $<0.001$ & 0.001 \\
\hline Mature & $155.13 \mathrm{bA}$ & $168.44 \mathrm{bA}$ & $213.23 \mathrm{aA}$ & $158.46 \mathrm{bA}$ & 173.82 & 5.90 & & & \\
\hline Average & 152.45 & 154.94 & 178.46 & 151.23 & & & & & \\
\hline \multicolumn{10}{|c|}{ Total Carbohydrates (TC, g. $\mathrm{kg}^{-1}$ Dry Matter) } \\
\hline Young & 764.47 & 762.17 & 721.94 & 764.80 & 753.34 & 6.11 & & & \\
\hline Intermediate & 771.85 & 749.20 & 731.42 & 748.89 & 750.34 & 5.74 & 0.001 & 0.255 & 0.126 \\
\hline Mature & 759.15 & 762.30 & 763.35 & 760.98 & 761.44 & 4.15 & & & \\
\hline Average & $765.16 \mathrm{a}$ & $757.89 \mathrm{ab}$ & $738.90 \mathrm{~b}$ & $758.22 \mathrm{ab}$ & & & & & \\
\hline \multicolumn{10}{|c|}{ Non-Fibrous Carbohydrates (NFC, g.kg ${ }^{-1}$ Dry Matter) } \\
\hline Young & 479.92 & 494.30 & 439.57 & 509.95 & 480.94 & 9.30 & & & \\
\hline Intermediate & 485.88 & 484.39 & 454.07 & 493.03 & 479.34 & 8.72 & $<0.001$ & 0.250 & $>0.050$ \\
\hline Mature & 489.26 & 485.03 & 405.72 & 477.31 & 464.33 & 9.75 & & & \\
\hline Average & $485.02 \mathrm{a}$ & 487.91a & $433.12 b$ & $493.43 a$ & & & & & \\
\hline
\end{tabular}

EPP (Opuntia stricta); APP (Opuntia undulata); F-08 (Opuntia atropes); V-19 (Opuntia larreri). SEM, standard error of mean; $G$, genotypes; $P$, phenological stages; $G \times P$, interaction of genotypes and phenological stages. Means followed by lowercase letters differ in the rows and capital letters in columns $(\mathrm{P}<0.05)$.

\subsection{Mineral Composition of Cladodes}

There was no effect of the factors $(\mathrm{P}>0.05)$ on the contents of minerals $\mathrm{N}$ (11.0 to 13.94 g.kg $\left.{ }^{-1} \mathrm{DM}\right), \mathrm{K}$ (24.22 to 39.18 g. $\left.\mathrm{kg}^{-1} \mathrm{DM}\right), \mathrm{Mg}$ (6.89 to $\left.7.39 \mathrm{~g} . \mathrm{kg}^{-1} \mathrm{DM}\right), \mathrm{S}$ (3.34 to 4.72 g.kg $\left.{ }^{-1} \mathrm{DM}\right), \mathrm{Fe}$ (93.4 to $\left.128.24 \mathrm{mg} . \mathrm{kg}^{-1} \mathrm{DM}\right)$ and $\mathrm{Zn}\left(52.04\right.$ to $\left.135.89 \mathrm{mg} \cdot \mathrm{kg}^{-1} \mathrm{DM}\right)$ (Figure 2 and Figure 3).

The $\mathrm{P}$ concentration in EPP was higher $(\mathrm{P}<0.05)$ in mature cladodes, similar to $\mathrm{V}-19$, but $\mathrm{V}-19$ exhibited a similar value in the intermediate stage (Figure 2b). In the APP genotype, the lowest concentration occurred in young cladodes. The $\mathrm{P}$ content in young and intermediate cladodes was higher in APP and F-08, but the highest concentration in mature cladodes was found in APP. 

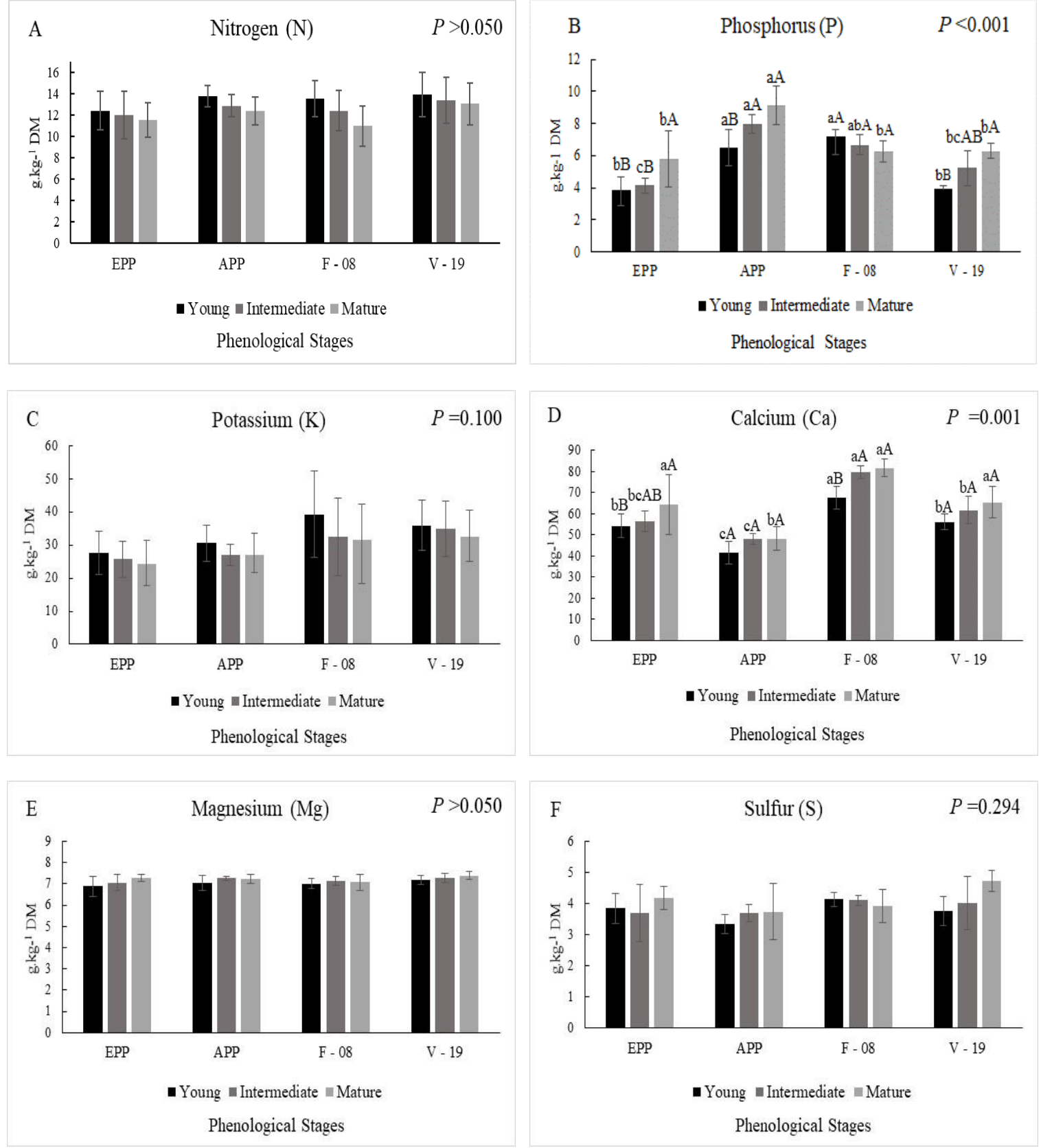

Figure 2. Macrominerals composition of species genotypes of the genus Opuntia spp. in different phenological stages. Lowercase letters compare the genotypes and capital letters compare the phenological stages ( $\mathrm{P}<0.05)$. EPP (Opuntia stricta); APP (Opuntia undulata); F-08 (Opuntia atropes); V-19 (Opuntia larreri)

Ca contents in EPP and F-08 genotypes were higher $(\mathrm{P}<0.05)$ in mature and intermediate cladodes. The lowest concentrations of Ca occurred at all stages of APP development (Figure 2d). Mineral B content was higher $(\mathrm{P}<0.05)$ in young and intermediate cladodes in EPP, APP and F-08 species. The lowest concentrations of B in the mature stage were found in F-08, and in the young and intermediate cladodes in V-19 (Figure 3a).

The APP and F-08 genotypes had the highest $(\mathrm{P}<0.05) \mathrm{Cu}$ contents in the young and intermediate cladodes. The highest $\mathrm{Cu}$ concentration in young cladodes was observed in APP 
and in the intermediate and mature stages in EPP and APP (Figure 3b).
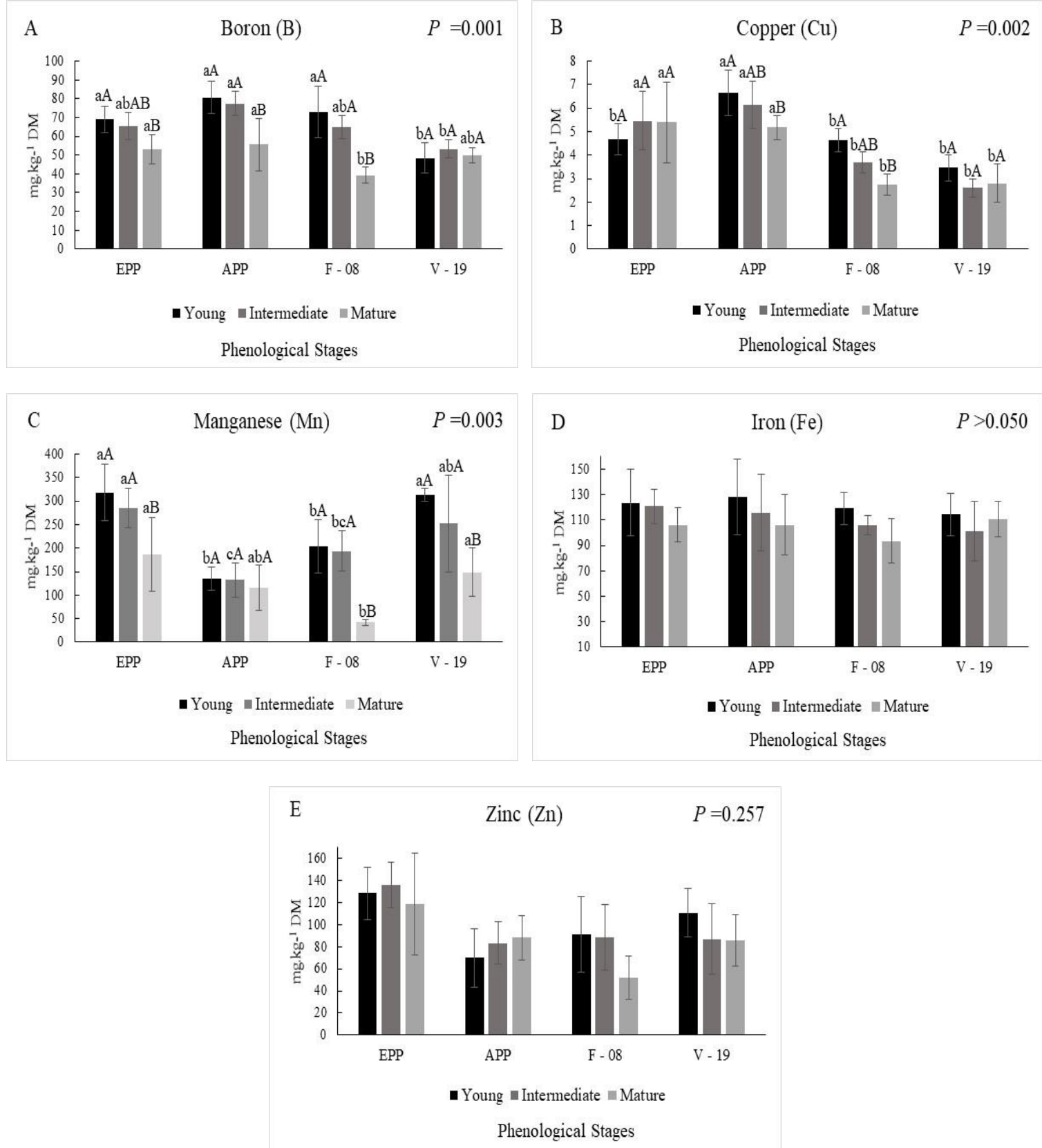

Figure 3. Microminerals composition of species genotypes of the genus Opuntia spp. in different phenological stages. Lowercase letters compare the genotypes and capital letters compare the phenological stages ( $\mathrm{P}<0.05)$. EPP (Opuntia stricta); APP (Opuntia undulata); F-08 (Opuntia atropes); V-19 (Opuntia larreri)

The Mn highest levels in EPP, F-08 and V-19 occurred in the young and intermediate cladodes. Values differed at developmental stages $(\mathrm{P}<0.05)$, mature cladodes at F-08 had lower Mn concentration, while higher concentrations at young and intermediate stages were observed at EPP and V-19 (Figure 3c). 


\subsection{Multivariate Data Analysis}

In the exploratory data analysis using PCA (Figure 4), the first two components (PC1 and PC2) explained $56.5 \%$ of the total data variation using all variables (Figure 4a), but by selecting the characteristics with the greatest potential for discrimination (11 variables) the contribution of these same components increased to $81.5 \%$ (Figure $4 \mathrm{f}$ ).

When all variables were used, the factor loadings CP, NFC, ADF, Fe, NDF and Ca showed a greater contribution for PC1 (Figure 4b), and TC, K, N, OM, MM and DM for PC2 (Figure 4c). High magnitude correlations occurred between TC x OM ( $\mathrm{r}=0.93), \mathrm{Zn} \times \mathrm{Mn}(\mathrm{r}=0.82)$, $\mathrm{Ca} \times \mathrm{MM}(\mathrm{r}=0.82), \mathrm{MM} \times \mathrm{OM}(\mathrm{r}=-1.00), \mathrm{MM} \times \mathrm{TC}(\mathrm{r}=-0.92)$ and NFC $\times$ NDF $(\mathrm{r}=-0.86)$ (Figure 4d).

By observing the dispersion of treatments in PC1 and PC2, five groups can be clearly distinguished (Figure 4e). Group 1 consisted of young and intermediate F-08 cladodes; group 2 formed by $\mathrm{V}-19$ in the intermediate and mature stages; group 3 consisting of young cladodes of EPP, APP and V-19 genotypes, and intermediates of EPP and APP; group 4 was formed by the mature stage of EPP and APP; and group 5 with the isolated mature F-08 cladodes.

The factor loadings of the selected variables NFC, CP, Ca, OM, MM and ADF had a greater contribution for PC1 (Figure 4g) and TC, N, K, NDF, OM and MM for PC2 (Figure 4h). High magnitude correlations occurred between TC x OM $(r=0.92), \mathrm{CP} \times \mathrm{NFC}(\mathrm{r}=0.82), \mathrm{CP}$ x Fe $(r=0.72), \mathrm{MM} \times \mathrm{TC}(\mathrm{r}=-0.92), \mathrm{CP} \times \mathrm{ADF}(\mathrm{r}=-0.86)$ and $\mathrm{Ca} \times \mathrm{OM}(\mathrm{r}=-0.82)$ (Figure $4 i)$. In the dispersion of treatments in PC1 and PC2, three groups were formed (Figure 4j): group 1 constituted by young and intermediate cladodes of F-08, group 2 constituted by cladodes of EPP, APP and V-19 in the three stages of development, and group 3 formed by the mature F-08 cladodes. 


\section{Macrothink}
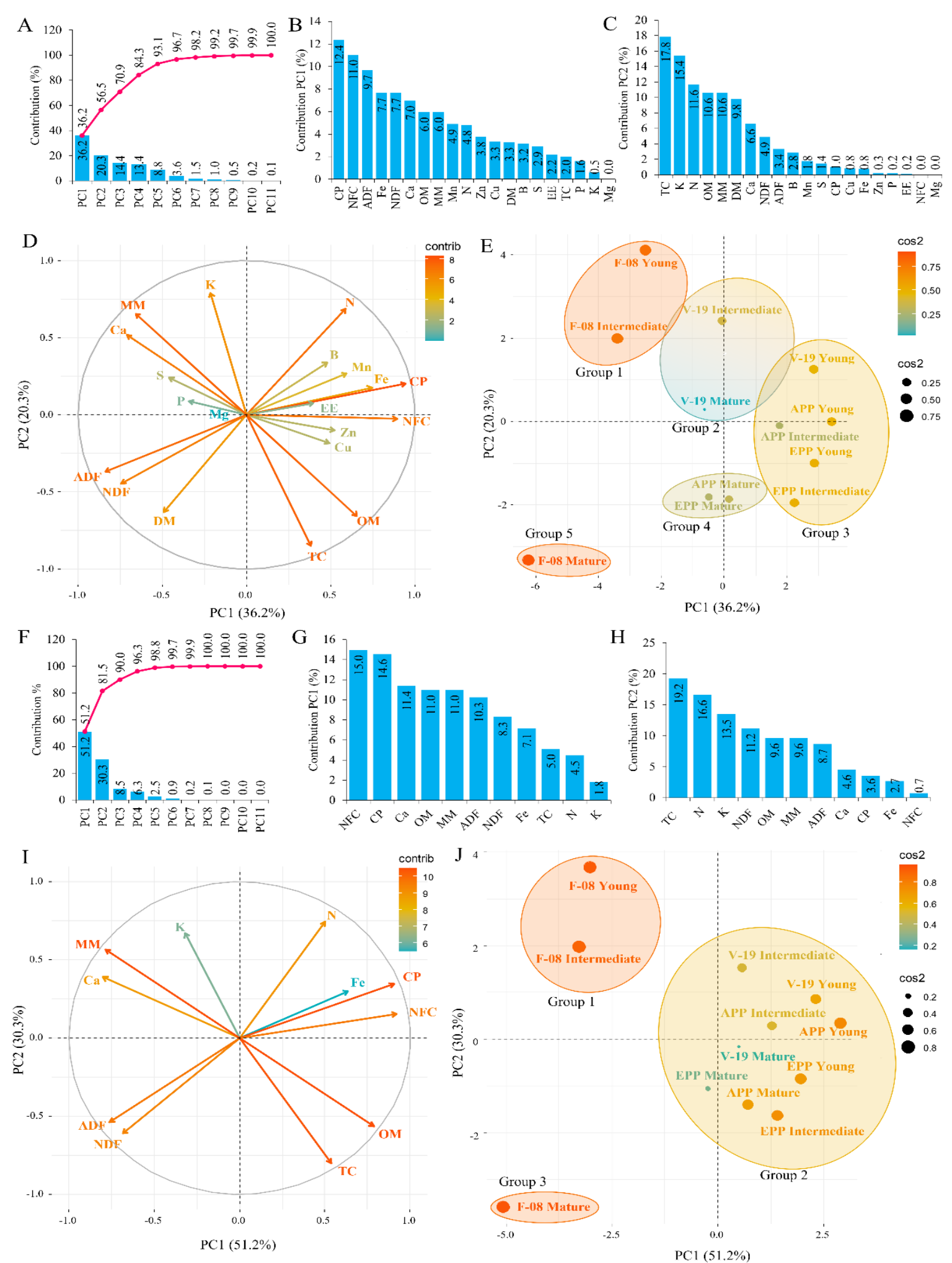

Figure 4. Analysis of principal components for chemical-bromatological and mineral composition of genotypes of species of the genus Opuntia spp. at different phenological stages. $A$ and $F$ individual and cumulative contribution of the main components as a function of all characteristics (A) and selected characteristics (F), $B$ and $G$ contribution of the first 
main component as a function of all characteristics (B) and selected characteristics $(\mathrm{G}), C$ and $H$ contribution of the second principal component as a function of all characteristics (C) and selected characteristics $(\mathrm{H}), D$ and $I$ circle correlation with the contribution of characteristics for the first two components with all characteristics (D) and selected characteristics (I). The arrows represent the direction of the feature, and the color gradient represents each one's contribution to the components. From blue to red, from low to high contributions. $E J$ distribution of treatments as a function of the first two components for all characteristics (E) and selected characteristics (J). The color gradient indicates the contribution of the first two components to explain the variation of treatments, also represented by the size of the circles that varies from 0.25 to $0.75(\mathrm{E})$ and 0.20 to $0.80(\mathrm{~J})$. EPP (Opuntia stricta), APP (Opuntia undulata), F-08 (Opuntia atropes), V-19 (Opuntia larreri).

\section{Discussion}

Opuntia ssp. are succulent plants and have a low DM content compared to other traditional forage plants. The values found (58.6 to $70.86 \mathrm{~g} \cdot \mathrm{kg}^{-1} \mathrm{DM}$ ) were lower compared to other studies with forage cactus (90.7 to 112.0 g. $\mathrm{kg}^{-1} \mathrm{NM}$ ) performed by Inácio et al. (2020) and Barros et al. (2018). This may be related to the higher cladodes water content in this study since they were collected in the rainy season. The lower concentration of DM in mature cladodes is probably due to increase in the proportion of supporting tissues that make possible supporting the expansion of new structures, in addition to the thickening and lignification of the cell wall (Chapman et al., 2014).

Due to the low content of DM in cladodes, the nutritional requirements of ruminants, fed exclusively on palm, may not be achieved, and it is necessary to complement diets based on Opuntia with other sources of roughage to optimize consumption. On the other hand, its inclusion in the diet reduces voluntary water intake by animals (Costa et al., 2012; Gouveia et al., 2019) since it supplies part of their water needs.

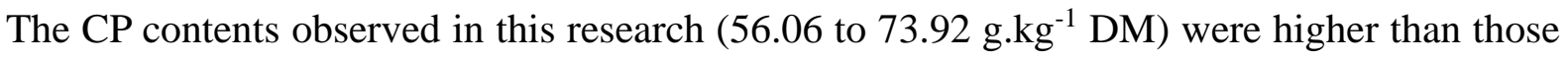
reported by Siqueira et al. (2018) (41.0 g. $\left.\mathrm{kg}^{-1} \mathrm{DM}\right)$ and Conceição et al. (2018) (55.5 g. $\mathrm{kg}^{-1}$ DM). These variations are attributed to soil moisture and fertility (Vazquez-Mendoza et al., 2017), and are directly related to the $\mathrm{N}$ content in cladodes (Figure 2a), as this element is one of the components of the protein. This means that an adequate supply of $\mathrm{N}$ for the plant is crucial to increase the concentration of $\mathrm{CP}$ in the cladodes.

The difference in $\mathrm{CP}$ content between mature and young cladodes can be explained by the cuticle thickening and the nitrogen components translocation to the developing structures. Mature cladodes have thicker cuticles due to expansion of the water storage parenchyma (very slowly degradable) at the expense of cell content (Astello-García et al., 2015). In this study, the CP in APP cladodes (71.08 g. $\left.\mathrm{kg}^{-1} \mathrm{DM}\right)$ and V-19 (71.24 g. $\left.\mathrm{kg}^{-1} \mathrm{DM}\right)$ are above the minimum necessary $\left(70.0\right.$ g. $\left.\mathrm{kg}^{-1} \mathrm{DM}\right)$ for ruminal microorganisms adequate growth and development, responsible for the degradation of nutrients in the fibrous fraction (Silva et al., 2011). 
Opuntia cladodes showed high concentrations of MM, similar to those described by Donato et al. (2014) (141.0 g.kg-1 DM) and Souza et al. (2010) (152.0 g. $\mathrm{kg}^{-1}$ DM). However, the F-08 species stood out in relation to the others, indicating that the accumulation of minerals differs within the genus. The increase in EE concentrations with cladode maturation, evidenced mainly in APP, acts as a plant energy reserve for carrying out biochemical and physiological processes under water stress conditions (Alves et al. 2016).

The increase in NDF and ADF contents with cladodium development (Table 4) was similar to what occurs in other forage plants. This fact was previously verified by Pinos-Rodríguez et al. (2010), by demonstrating that there is a linear relationship between the maturation of Opuntia and the increase in fibrous fractions. This happens because as the physiological age of the plant advances, the cell wall becomes thicker with an increase in the concentrations of cellulose, hemicellulose, and lignin, implying an increase in fibrous proportions. However, it seems to have a negative impact on the content of nitrogenous compounds, since with the maturation of the cladodes the CP is lower $\left(64.88 \mathrm{~g}_{\mathrm{gg}} \mathrm{kg}^{-1} \mathrm{DM}\right)$.

The higher ADF concentration in mature F-08 cladodes may indicate that the DM digestibility in this species tends to be lower compared to the others, as these characteristics are inversely proportional. On the other hand, the NDF of the studied species (254.8 to 357.6

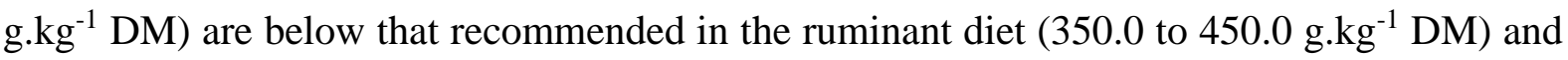
can reduce the total chewing time and saliva secretion, essential to keep the rumen environment stable and maximize production (Vilela et al., 2010). Therefore, Opuntia cladodes must be provided in association with a physically effective fiber source, such as silage, hay, crop residues and sugarcane bagasse, in order to avoid possible metabolic disturbances.

TC were the most abundant DM components, and the genotypes have a high concentration of NFC, which was not altered by cladode maturation. NFC contents are higher than most bulky feeds commonly used in rations, suggesting that Opuntia cladodes have the potential to replace other sources of energy concentrate in the diet (Costa et al., 2012; Felix et al., 2016). Furthermore, the rapid fermentation of these carbohydrates favors ruminal microorganisms and contributes to microbial protein synthesis (McDonald et al., 2011).

As minerals are directly related to nutrient absorption, physiological status, DM intake and performance of ruminants, the nutritional requirements of each animal category must be considered when confronting with the amount of minerals present in Opuntia cladodes.

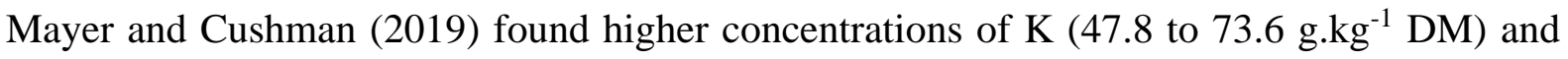

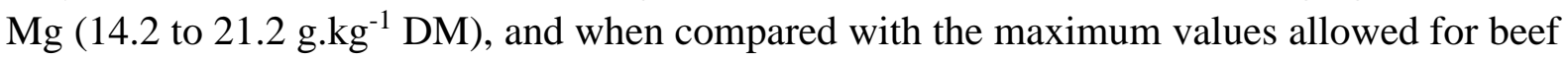
cattle during the pregnancy and lactation, found that it was above tolerable levels. The mineral concentrations in the studied cactus forage species meet the nutritional requirements of cattle in these categories, but the tolerance of $\mathrm{Ca}$ is exceeded in all genotypes and $\mathrm{K}$ tolerance is exceed in F-08 and V-19.

The $\mathrm{P}$ concentration in mature cladodes (Figure $2 \mathrm{~b}$ ) is certainly related to the participation of this mineral in the photosynthesis and respiration processes of plants with CAM metabolism, since more developed organs produce a greater amount of photosynthates (Queiroz et al., 
2015). In animal nutrition, cladodes with higher $P$ contents may contribute to supplement part of the deficiency often found in goats raised extensively in semiarid regions (Barbosa et al., 2018).

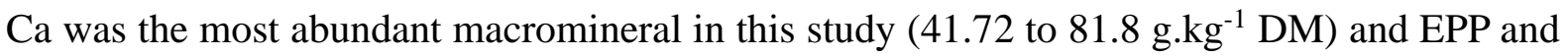
F-08 contents increased with cladode maturation. According to Hernandez-Urbiola et al. (2011), the concentration of this mineral in $O$. ficus increased with the plant aging, corroborating the results of this research. Ca accumulation in cladodes may be related to heat stress, where it is able to mitigate the effects by improving stomatal function and other cellular processes (Contreras-Padilla et al., 2011).

Higher $\mathrm{Ca}$ than $\mathrm{P}$ contents, result in a high $\mathrm{Ca}: \mathrm{P}$ ratio. The unbalance of these minerals in the forage can cause the appearance of kidney stones and affect the performance (Santos et al., 2009). However, the main form of $\mathrm{Ca}$ in cladodes is calcium oxalate (McConn \& Nakata 2004; Tovar-Puente et al., 2007), which makes this mineral unavailable and inhibits poisoning in animals. From a nutritional point of view, both minerals are interesting for livestock feed, essential for bone formation, ionic balance, and signal transmission within cells (Agabriel 2010).

The concentration of $\mathrm{B}, \mathrm{Cu}$ and $\mathrm{Mn}$ in young and intermediate cladodes suggests that they are required in greater amounts by developing tissues. This nutrient redistribution process is essential to the plant life cycle, as some minerals increase in the area part, others decrease, resulting in translocation (Lima et al., 2011). Thus, the cladodes supply in young and intermediate stages, located in the extremities or median portion of the plant, can be aimed at animal categories with greater demand for these minerals.

Among the microminerals, Mn was the most abundant in Opuntia species (41.6 to 317.7 $\mathrm{mg} \cdot \mathrm{kg}^{-1} \mathrm{DM}$ ), showing typical behavior of a nutrient synthesized in larger amounts in young structures (Figure 3c). Alves et al. (2017) observed differences in Mn concentration between secondary and tertiary order cladodes, despite not defining a pattern of accumulation in the plant, ranging from 228.5 to $512.5 \mathrm{mg} \cdot \mathrm{kg}^{-1} \mathrm{DM}$ in $O$. stricta, from 102.5 to $139.47 \mathrm{mg}$. $\mathrm{kg}^{-1}$ DM for $O$. atropes, and from 323.5 to $523.9 \mathrm{mg} . \mathrm{kg}^{-1} \mathrm{DM}$ for $O$. larreri.

In the exploratory analysis using PCA, the variables $\mathrm{EE}, \mathrm{P}, \mathrm{Mg}, \mathrm{S}, \mathrm{B}, \mathrm{Cu}, \mathrm{Zn}$ and $\mathrm{Mn}$ had a minor contribution to the divergence between treatments (Figure $4 \mathrm{~b} ; 4 \mathrm{c}$ ). When disregarding them, the accumulated value of the first principal components was greater than $80 \%$, which according to Cruz et al. (2012) is sufficient to explain the variability of the data. In the formation of groups, F-08 presented lower nutritional quality compared to the other species, using all characteristics and selected characters (Figure 4e; 4j), explained by the strong contribution of the variables $\mathrm{ADF}$ and $\mathrm{MM}$ in mature cladodes, while $\mathrm{Ca}, \mathrm{K}$, and $\mathrm{MM}$ explain in the young and intermediate stages of development.

\section{Conclusions}

The cladodes of the species $O$. stricta, $O$. undulata and $O$. larreri showed a better nutritional quality for ruminant feeding. Young and intermediate cladodes are more proteinaceous and less fibrous. These results can be useful in selecting the forage cactus species with superior 
nutritional quality and in optimizing the use of cladodes for feeding ruminants of different categories in semiarid regions.

\section{Acknowledgments}

The authors thank the National Council for Scientific and Technological Development (CNPq) for the granting of a postgraduate scholarship and to the Coordination for the Improvement of Higher Education Personnel (CAPES).

\section{References}

Agabriel, J. (2010). Alimentation des bovins, ovins et caprins: besoins des animaux, valeurs des aliments: Tables Inra 2007. Editions Quae, Versailles, France.

Alves, F. A. L., Andrade, A. P., Bruno, R. L. A., \& Santos, D. C. (2016). Study of the variability, correlation and importance of chemical and nutritional characteristics in cactus pear (Opuntia and Nopalea). African Journal of Agricultural Research, 11(31), 2882-2892. https://doi.org/10.5897/AJAR2016.11025

Alves, F. A. L., Andrade, A. P., Bruno, R. L. A., Santos, D. C., Magalhães, A. L. R., \& Silva, D. S. (2017). Chemical and Nutritional Variability of Cactus Pear Cladodes, Genera Opuntia and Nopalea. American Journal of Food Technology, 12(1), 25-34. https://doi.org/10.3923/ajft.2017.25.34

AOAC (Association of Official Analytical) (1990). Official methods of analysis, 15th ed. International official methods of analysis, Washington, DC.

Astello-García, M. G., Cervantes, I., Nair, V., Santos-Díaz, M. S., Reyes-Agüero, A., Guéraud, F., ... \& La Rosa, A. P. B. (2015). Chemical composition and phenolic compounds profile of cladodes from Opuntia spp. cultivars with different domestication gradient. Journal of Food Composition and Analysis, 43, 119-130. https://doi.org/10.1016/j.jfca.2015.04.016

Barbosa, F. P. S., Almeida, V. M., Albuquerque, R. F., Rocha, B. P., Soares, P. C., Filho, G. B. S., Chaves, H. A., \& Mendonça, F. S. (2018). Deficiência de fósforo em caprinos no semiárido de Pernambuco. Pesquisa Veterinária Brasileira, 38(6), 1117-1124. https://doi.org/10.1590/1678-5150-PVB-5395

Barros, L. J. A., Ferreira, M. A., Oliveira, J. C. V., Santos, D. C., Chagas, J. C. C., Alves, A. M. S. V., Silva, A. E. M., \& Freitas, W. R. (2018). Replacement of Tifton hay by spineless cactus in Girolando post-weaned heifers' diets. Tropical Animal Health and Production, 50(1), 149-154. https://doi.org/10.1007/s11250-017-1415-4

Batista, A. M. V., Ribeiro Neto, A. C., Lucena, R. B., Santos, D. C., Dubeux Júnior, J. C. B., $\&$ Mustafa, A. F. (2009). Chemical composition and ruminal degradability of spineless cactus grown in northeas Brazil. Rangeland Ecology \& Management, 62(3), 297-301. https://doi.org/10.2111/07-099R1.1

Chapman, D. F., Lee, J. M., \& Waghorn, G. C. (2014). Interaction between plant physiology and pasture feeding value: a review. Crop and Pasture Science, 65(8), 721-734. 
https://doi.org/10.1071/CP13379

Cody, R. (2015). An introduction to SAS University Edition. SAS Institute Inc., Cary.

Conceição, M. G., Ferreira, M. A., Silva, J. L., Costa, C. T. F., Chagas, J. C. C., \& Monteiro, C. C. F. (2018). Can cactus (Opuntia stricta [Haw.] Haw) cladodes plus urea replace wheat bran in steers' diet? Asian-Australasian Journal of Animal Sciences, 31(10), 1627-1634. https://doi.org/10.5713/ajas.17.0927

Contreras-Padilla, M., Pérez-Torrero, E., Hernández-Urbiola, M. I., Hernández-Quevedo, G., Del-Real, A., Rivera-Muñoz, E. M., \& Rodríguez-García, M. E. (2011). Evaluation of oxalates and calcium in nopal pads (Opuntia ficus-indica var. redonda) at different maturity stages. Journal of Food Composition and Analysis, 24, 38-43. https://doi.org/10.1016/j.jfca.2010.03.028

Cordova-Torres, A. V., Mendoza-Mendoza, J. C., Bernal-Santos, G., García-Gasca, T., Kawas, J. R., Costa, R. G., Jacobo, M. C., \& Andrade-Montemayor, H. M. (2015). Nutritional composition, in vitro degradability and gas production of Opuntia ficus indica and four other wild cacti species. Life Sciences, 12(2), 42-54.

Costa, R. G., Hernandez, T. I., Medeiros, G. R., Medeiros, A. N., Azevedo, P. S., Pinto, T. F., \& Delgado, J. V. (2012). Consumo de água de ovinos alimentados con diferentes niveles de nopal (Opuntia ficus indica) en Brasil. Archivos de Zootecnia, 61(234), 301-304. https://doi.org/10.4321/S0004-05922012000200015

Cruz, C. D., Regazzi, A. J., \& Carneiro, P. C. S. (2012). Modelos biométricos aplicados ao melhoramento genético. 4th ed. Viçosa: UFV.

Donato, P. E. R., Pires, A. J. V., Donato, S. L. R., Silva, J. A., \& Aquino, A. A. (2014). Valor nutritivo da palma forrageira 'gigante' cultivada sob diferentes espaçamentos e doses de esterco bovino. Revista Caatinga, 27(1), 163-172.

Dubeux, Jr. J. C. B., Santos, M. V. F., Cunha, M. V., Santos, D. C., Souza, R. T. A., Mello A. C. L., \& Souza, T. C. (2021). Cactus (Opuntia and Nopalea) nutritive value: A review. Animal Feed Science and Technology, 275, 114890. https://doi.org/10.1016/j.anifeedsci.2021.114890

Edvan, R. L., Mota, R. R. M., Dias-Silva, T. P., Nascimento, R. R., Sousa, S. V., Silva, A. L., Araújo, M. A., \& Araújo, J. S (2020). Resilience of cactus pear genotypes in a tropical semi-arid region subject to climatic cultivation restriction. Scientific Reports, 10, 10040. https://doi.org/10.1038/s41598-020-66972-0

Felix, S. C. R., Pessoa, R. A. S., Ferreira, M. A., Soares, L. F. P., Silva, J. L., Abreu, K. S. F., \& Melo, A. C. C. (2016). Intake, performance, and carcass characteristics of lambs fed spineless cactus replacing wheat bran. Tropical Animal Health and Production, 48(2), 465-468. https://doi.org/10.1007/s11250-015-0969-2

Ferraz, R. L. S., Costa, P. S., Neto, J. D., Anjos, F. A., Barreto, N. P., Soares, L. S., Magalhães, I. D., \& Barbosa, M. A. (2017). Opuntia ficus-indica (L.) Mill. (Cactaceae) in climate change scenarios and its potential for wastewater bioremediationin Semi-arid Regions: a systematic 
review and meta-analysis. Tropical Animal Health and Production, 18(3), 1-11. https://doi.org/10.9734/JEAI/2017/36730

Gouveia, L. N. F., Soares, P. C., Moura, M. S. C., Silva, T. G. P., Silva Neto, L. F., Guimarães, D. N. A., Cardoso, D. B., Batista, Â. M. V., \& Carvalho, F. F. R. (2019). Metabolic profile and renal function of lambs fed with maniçoba hay replacement by spineless cactus. Revista Agrária Acadêmica, 2(4),

107-114. https://doi.org/10.32406/v2n42019/41-51/agrariacad

Hernandez-Urbiola, M. I., Perez-Torrero, E., Rodriguez-García, M. E. R. (2011). Chemical Analysis of Nutritional Content of Prickly Pads (Opuntia ficus indica) at Varied Ages in an Organic Harvest. International Journal of Environmental Research and Public Health, 8, 1287-1295. https://doi.org/10.3390/ijerph8051287

Inácio, J. G., Conceição, M. G., Santos, D. C., Oliveira, J. C. V., Chagas, J. C. C., Moraes, G. S. O., Silva, E. T. S., \& Ferreira, M. A. (2020). Nutritional and performance viability of cactus Opuntia based to concentrate levels for Girolando lactating dairy cows. Asian-Australasian Journal of Animal Sciences, 33(1), 35-43. https://doi.org/10.5713/ajas.18.0916

INMET (Instituto Nacional de Meteorologia) (2019). Parâmetros meteorológicos de Arcoverde, Pernambuco. http://www.inmet.gov.br/

Lima, R. L. S., Severino, L. S., Cazetta, J. O., Azevedo, C. A. V., Sofiatti, V., \& Arriel, N. H. C. (2011). Redistribuição de nutrientes em folhas de pinhão-manso entre estádios fenológicos. Revista Brasileirade Engenharia Agricola e Ambiental, 15(11), 175-1179. http://dx.doi.org/10.1590/S1415-43662011001100010

Lucena, C. M., Lucena, R. F. P., Costa, G. M, Carvalho, T. K. N., Costa, G. G. S., Alves, R. R. N., Pereira, D. D., Ribeiro, J. E. S., Alves, C. A. B, Quirino, Z. G. M., \& Nunes, E. N. (2013). Use and knowledge of Cactaceae in Northeastern Brazil. Journal of Ethnobiology and Ethnomedicine, 9, 1-11.

Malavolta, E., Vitti, G. C., \& Oliveira, S.A. (1997). Avaliação do estado nutricional das plantas: princípios e aplicações. 2th ed. Piracicaba: Potafos.

Mayer, J. A., \& Cushman, J. C. (2019). Nutritional and mineral content of prickly pear cactus: a highly water-use efficient forage, fodder and food species. Journal of Agronomy and Crop Science, 205(6), 625-634. https://doi.org/10.1111/jac.12353

McConn, M. M., \& Nakata, P. A. (2004). Oxalate reduces calcium availability in the pads of the prickly pear cactus through formation of calcium oxalate crystals. Journal of Agricultural and Food Chemistry, 52(5), 1371-1374. https://doi.org/10.1021/jf035332c

McDonald, P., Edwards, R. A., Greenhalgh, J. F. D., Morgan, C. A., Sinclair, L. A., \& Wilkinson, R. G. (2011). Animal nutrition. 7th ed. Harlow, UK: Pearson Education.

Moraes, G. S. O., Guim, A., Tabosa, J. N., Chagas, J. C. C., Almeida, M. P., \& Ferreira, M. A. (2019). Cactus [Opuntia stricta (Haw.) Haw] cladodes and corn silage: how do we maximize 
the performance of lactating dairy cows reared in semiarid regions? Livestock Science, 221, 133-138. https://doi.org/10.1016/j.livsci.2019.01.026

Oliveira, J. F. F., Andrade, A. P., Valença, R. L., Cunha, G. L. C., Araújo, F. S., Magalhães, \& A. L. R. (2021). Metabólitos secundários presentes na palmeira forrageira: benefícios e potencialidades. Research, Society and Development, $\quad$ 10(2), e53910212809. http://dx.doi.org/10.33448/rsd-v10i2.12809

Pinos-Rodríguez, J. M., Velázquez, J. C., González, S. S., Aguirre, J. R., García, J. C., Álvarez, G., \& Jasso, Y. (2010). Effects of cladode age on biomass yield and nutritional value of intensively produced spineless cactus for ruminants. South African Journal of Animal Science, 40, 245-250.

Queiroz, M. G, Silva, T. G. F., Zolnier, S., Silva, S. M. S., Lima, L. R., \& Alves, J. D. O. (2015). Morphophysiological characteristic and yield of forage cactus under different irrigation depths. Revista Brasileira de Engenharia Agrícola, 19, 931-938. http://dx.doi.org/10.1590/1807-1929/agriambi.v19n10p931-938

$\mathrm{R}$ Core Team (2018). $R$ : A language and environmental for statistical computing. $R$ foundation for statistical computing. Viena, Austria. https://www.R-project.org/

Santos, K. L. L., Guim, A., Batista, Â. M. V., Soares, P. C., Souza, E. J. O., \& Araújo, R. F. S. S. (2009). Balanço de macrominerais em caprinos alimentados com palma forrageira e casca de soja. Revista Brasileira de Saúde e Produção Animal, 10(3), 546-559.

Senger, C. C. D., Kozloski, G. V., Sanchez, L. M. B., Mesquita, F. R., Alves, T. P., \& Castagnino, D. S. (2008). Evaluation of autoclave procedures for fibre analysis in forage and concentrate feedstuffs. Animal Feed Science and Technology, 146, 169-174. https://doi.org/10.1016/j.anifeedsci.2007.12.008

Silva, C. (2009). Manual de análises químicas de solos, plantas e fertilizantes. 2th ed. Brasília: Embrapa Informações Tecnológicas.

Silva, R. R., Sampaio, E. V. S. S. (2015). Palmas forrageiras Opuntia ficus-indica e Nopalea cochenillifera: sistemas de produção e usos. Revista Geama, 2, 131-141.

Silva, T. G. P., Batista, Â. M. V., Guim, A., Silva, Jr. V. A., Carvalho, F. F. R., Barros, M. E. G., Sousa, D. R., \& Silva, S. M. C. (2019). Histomorphometric changes of the fore stomach of lambs fed diets containing spineless cactus genotypes resistant to Dactylopius sp. Tropical Animal Health and Production, 52, 1299-1307. https://doi.org/10.1007/s11250-019-02129-0

Silva, V. L., Costa, L. S., Bastos, M. P. V., Facuri, L. M. A. M., Rego, N. O. Jr., \& Silva, M. V. (2011). Caracterização físico-química e bioquímica do farelo de palma forrageira redonda (Opuntia ficus) utilizado na alimentação de ruminantes. Pubvet, 5(2), 1-13.

Siqueira, M. C. B., Ferreira, M. A., Monnerat, J. P. I. S., Silva, J. L., Costa, C. T. F., Conceição, M. G., Soares, A. A., Andrade, L. B., \& Chagas, J. C. C. (2018). Nutritional performance and metabolic characteristic of cattle fed spineless cactus. Journal of Agricultural Science and Technology, 20, 13-22. 
Sniffen, C. J., O’Connor, J. D., Van Soest, P. J., Fox, D. G., \& Russel, J. B. (1992). A net carbohydrate and protein system for evaluating cattle diets: II. Carbohydrate and protein availability. Journal of Animal Science and Biotechnology, 70, 3562-3577. https://doi.org/10.2527/1992.70113562x

Souza, C. M. S., Medeiros, A. N., Furtado, D. A., Batista, A. M. V., Pimenta Filho, E. C., \& Silva, D. S. (2010). Desempenho de ovelhas nativas em confinamento recebendo palma-forrageira na dieta na região do semiárido nordestino. Revista Brasileira de Zootecnia, 39(5), 1146-1153. https://doi.org/10.1590/S1516-35982010000500028

Teixeira, P. C., Donagema, G. K., Fontana, A., \& Teixeira, W. G. (2017). Manual de métodos de análise de solo. 3th ed. Brasília: Embrapa.

Tovar-Puente, A., Pando-Moreno, M., González-Rodríguez, H., Scott-Morales, L., \& Méndez-Gallegos, S. J. (2007). Density of calcium oxalate crystals in 15 prickly pear cultivated species. Journal of the Professional Association for Cactus Development, 9, 91-98.

Van Soest, P. J., Robertson, J. B., \& Lewis, B. A. (1991). Methods for dietary fiber, neutral detergent fiber, and nonstarch polysaccharides in relation to animal nutrition. Journal of Dairy Science, 74, 3583-3597. https://doi.org/10.3168/jds.S0022-0302(91)78551-2

Vazquez-Mendoza, P., Miranda-Romero, L. A., Aranda-Osorio, G., Burgueño-Ferreira, J. A., \& Salem, A. Z. M. (2017). Evaluation of eleven Mexican cultivars of prickly pear cactus trees for possibly utilization as animal fed: in vitro gas production. Agroforestry Systems, 91, 749-756. https://doi.org/10.1007/s10457-016-9947-6

Velásquez, P. A. T., Berchielli, T. T., Reis, R. A., Rivera, A. R., Dian, P. H. M., \& Teixeira, I. A. M. A. (2010). Composição química, fracionamento de carboidratos e proteínas e digestibilidade in vitro de forrageiras tropicais em diferentes idades de corte. Revista $\begin{array}{llll}\text { Brasileira de } \quad \text { Zootecnia, } & 39(6), & 1206-1213 .\end{array}$ https://doi.org/10.1590/S1516-35982010000600007

Vilela, M. S., Ferreira, M. A., Azevedo, M., Modesto, E. C., Farias, I., Guimares, A. V., \& Bispo, S. V. (2010). Effect of processing and feeding strategy of the spineless cactus (Opuntia ficus-indica Mill.) for lactating cows: Ingestive behavior. Applied Animal Behaviour Science, 125, 1-8. https://doi.org/10.1016/j.applanim.2010.03.005

\section{Copyright Disclaimer}

Copyright for this article is retained by the author(s), with first publication rights granted to the journal.

This is an open-access article distributed under the terms and conditions of the Creative Commons Attribution license (http://creativecommons.org/licenses/by/4.0/). 